\title{
Renaissance Monti di Pietà in Modern Scholarship: Themes, Studies, and Historiographic Trends ${ }^{1}$
}

\author{
NICOLA LORENZO BARILE
}

University of Bari

Il existe une longue tradition d'études des Monti di Pietà, qui est presqu'entièrement publiée en italien. Cet article propose une revue historiographique de ces recherches, en se basant sur quatre thèmes centraux les ayant orientées. Le premier de ces thèmes correspond aux relations entre les banques et les premiers Monti, et à la question de savoir s'ils étaient de véritables banques ou des institutions charitables. Le deuxième thème correspond au contexte de ces pratiques formé par les débats théologiques et les opinions juridiques de la fin du Moyen Âge et de la Renaissance. Le troisième thème est centré sur l'influence des prédicateurs franciscains, incluant comment leurs discours antisémites ont été contrebalancés par les préoccupations économiques locales, pour former un compromis pratique. Le quatrième thème correspond au rôle et à la fonction qu'ont joués les Monti dans le Royaume de Naples. En conclusion, cette revue examine les recherches sur les Monti publiées en anglais depuis les années 1930.

7 here is a long tradition of studying Italy's charitable pawn banks, or monti di pieta, ahistorically, as either a chapter in the history of local pious institutions, an issue related to late medieval scholastic discussions of usury, or an argument in the debate on the medieval origins of modern banking. ${ }^{2}$ By examining a few principal themes, as these have been developed in both Italian and English language studies, we can see how the monti are now emerging as a distinct subject of research fully integrated into larger historiographical trends relating to sources, methodologies, and questions. This review of the literature will trace the background, developments, and current state of research on a few topics related to the Italian monti, chiefly:

1. The monti di pietà and the banks: questions of origins

2. Theological and legal contexts: ideas and sources 
3. Franciscans, Jews, and local dynamics

4. The monti di pietà and the Kingdom of Naples

5. Studies in English

\section{The monti di pietà and the banks: questions of origins}

Local histories of the monti have long been obsessed with the search for primacy, and this has generated many "myths of origins."3 Current research holds that Umbria and the Marches were the most fertile terrain for the foundation of the first monti. ${ }^{4}$ Many early studies identified Perugia as the first in 1462, and the arguments for this identification remain strong, in part because Pope Innocent VIII later held it up as the model to follow. ${ }^{5}$ Some scholars have argued that the first identifiable monte emerged four years earlier in Ascoli Piceno in 1458 as the work of the Franciscan Observant Friar Domenico da Leonessa, though the documentation in support of this is weak. ${ }^{6}$ Since a fire in 1535 destroyed the communal archives of Ascoli Piceno, including the greater part of the documents relative to the monte di pietà, the historian Giacinto Pagnani reconstructed its founding events by using the 1468 statutes of the monte at Recanati, also founded by Fra Domenico da Leonessa, which are extant. ${ }^{7}$

Civic statutes regulated many corporate groups such as confraternities, guilds, and monti di pietà. ${ }^{8}$ Civic, confraternal, and monte statutes sometimes give valuable lists of rules governing various aspects of the activities of the monte, including the duration of loans, maximum amounts, the value and type of acceptable pawned articles, the number of contracts necessary, the duties of officials, and the means of raising capital. The statutes for various monti di pietà represent a particularly important source for dating and reconstructing their activities, and this is why we often find them published in appendices to articles and volumes.

At the same time, statutes are limited in that they fail to offer any specific explanation of the later history of local monti di pietà. Pagnani's use of the monte in Recanati is revealing. Bernardino Ghetti had investigated it as early as 1907, and scholars since have taken it as the model of a monte. Yet when aiming to explain its closing in 1507 , Ghetti mentioned only rather vaguely that there had been some interference on the part of the commune. ${ }^{9}$ It is clear that the real aim of many of the studies of the first monti di pietà in Umbria 
and the Marches was not so much to describe and understand the development of the institution as it was to search for the "ideal type" of monte that could serve as a model for others to copy. With few exceptions, only in recent years have scholars moved beyond studies focused mainly on exploring origins and establishing that "their" monte was in some way the first one or in some other way distinctive. ${ }^{10}$

The geographical, chronological, and analytical limits of many studies can be explained in part by the fact that local banks and bank foundations have been among the main sources of funding for research and publication into Renaissance monti. Thanks to their resources and ready access to documents, they have underwritten the research projects, conferences, and publications that have shaped the field. ${ }^{11}$ They have also brought their own pre-occupations. The support of banks and their foundations helped foster a particular historiographical school of thought about the monti di pietà that studied their origins and, for much of the twentieth century, aimed to define their nature, asking particularly whether the monti di pietà were charitable institutions or forerunners of modern banks.

The two entries written for the Enciclopedia Italiana in the 1930s by Gino Luzzatto and Armando Sapori exemplified the two very different directions that research was taking at the time into the question of whether monti di pietà were fundamentally charitable institutions (Luzzatto) or banks (Sapori). ${ }^{12}$ In the 1950s, Giuseppe Mira followed Luzzatto in arguing the former case, since many monti were founded by the Franciscan Observant Friars, an order focused on charity, and much of the initial capital was generated from donations and bequests from private individuals. ${ }^{13}$ Mira limited his analysis to monti such as those of Perugia and Orvieto that relied on volunteer employees and that did not charge for short-term loans.

Armando Sapori, on the other hand, emphasized that monti were precursors of banks. Certainly they arose in order to liberate the poor from debts they had contracted with usurers, and particularly Jewish usurers. Gradually, however, by expanding the activities by which they generated capital and financed works of charity, most monti ended up becoming genuine banking institutions. ${ }^{14}$ Writing in the 1960s, Gino Barbieri developed a similar approach, and was unwilling to see the monti simply as "praiseworthy charitable works of a trifling nature within the sphere of the miserably poor." He argued that the 
monti functioned as a force for controlling the cost of money, to the advantage of labour, and for supplying credit for production and commerce. ${ }^{15}$ Barbieri here followed John Maynard Keynes, who reevaluated the social advantage of the medieval laws on the prohibition of usury as discouraging excessive interest rates. In reality, there is nothing in the works of medieval theologians or jurists that might even vaguely suggest the Keynesian concept of the "marginal efficiency of capital" or a "preference for liquidity." ${ }^{16}$

The economist Giuseppe Garrani wrote at the same time and in the same vein. Because both the founders of the monti and Keynes approved of lower interest rates, Garrani argued that Keynes could actually be considered "among the late but important defenders of the monti di pietà." ${ }^{17}$ For Garrani, in fact, the monti di pietà were not charitable institutions at all, given that their founders aimed to offer interest rates lower than those of the usurers, thereby addressing the lack of ordinary credit for the population. Despite his training as an economist, Garrani did not use the accounting sources of the monti but depended solely on their statutes, in the most important cities of Italy, to set up a comparison among their regulations. Garrani's book received mixed reviews, with one historian arguing that he had misunderstood "the animating spirit of the institution," which was always and uniquely a spirit of doing good, even while operating like a bank. ${ }^{18}$

Some of these questions have been worked out in relation to the monti of Tuscany, which generally have not received as much attention as one would expect. The Monte di Pietà of Pistoia, founded in 1473, was the first in the region, but the first major study of it was not published until 1976 in conjunction with its quincentenary. Supported by the local Cassa di Risparmio, this history was written with the deliberate intent of connecting with David Herlihy's previous study of early medieval Pistoia. ${ }^{19}$ Authors Ilvo Capecchi and Lucia Gai made use of the various redactions of the statutes of the monte, published in an appendix to their volume, and consulted the deliberations of city councils and commissions charged with "reforming" the monte rules. While aiming for completeness, they made little use of private documents such as the 1491 register for the sale of its pawned items (which they did however publish in an appendix), and they failed to mention the extant 1553 ledger of the monte's creditors and debtors. Attentive examination of those documents would have allowed Capecchi and Gai to consider individual clients, but these documents did not fit into the restricted time span they were considering. Moreover, such 
documents would have been of little help in supporting one of the stated goals of their research, which was to establish "a continuity between those institutions of the past and today's banks, with particular reference to the Casse di Risparmio and the monti di pietà." 20

The argument that the monti di pietà were primarily like banks has been picked up recently by Tommaso Fanfani, though it otherwise finds little favour today. Approaches that emphasize either the charitable or banking character of the monti di pietà are now considered outmoded, as most historians see monti as having been organically and inseparably both of those things. ${ }^{21}$

The rise of confraternity studies aids in this new approach, since it sets the emergence and development of monti into an institutional context that thoroughly blends religious motivations with lay social and economic realities. In fact, across Italy confraternities provided the most common organizational form for new monti from the fifteenth into the eighteenth centuries. ${ }^{22}$

\section{Theological and legal contexts: ideas and sources}

Garrani published his book in 1957, the same year that John Thomas Noonan Jr. published The Scholastic Analysis of Usury. Noonan considered the monti di pietà as charitable institutions and defined them as "a public pawnshop, regularly financed by charitable donations and run not for profit but for the service of the poor." In order to reconstruct the rise of the monti, he referred to the works of such theologians and canonists as Niccolò Bariani, Bernardino de Busti, and, above all, Tommaso de Vio, known as Cardinal Cajetan, who discussed the possibility of asking for "a small fee for [the monte's] care of the pawns and for administrative expenses." Noonan was convinced that the monti di pietà represented "a momentous break from the past." ${ }^{23}$ That the monti di pietà were a novelty in medieval Italy was already apparent from the words of Bernardino da Feltre and Marco da Montegallo, and from the consilia of Giovani Battista Caccialupi and Gomezio of Lisbon. ${ }^{24}$ While Noonan's book was positively received in the United States, Italian historians believed that the medieval usury prohibition was by no means an indisputable and inflexible rule, but rather that medieval society accepted a logic of profit, with the monti di pietà providing a prime example. ${ }^{25}$ 
More recently, Maria Giuseppina Muzzarelli has reexamined the disputes that animated the last decades of the fifteenth century, when the monti first emerged. Gino Barbieri reviewed the debates among scholastics, but events were shaped more profoundly by the preaching of Franciscan Observants like Bernardino da Feltre. ${ }^{26}$ One can compare Bariani and Cardinal Cajetan on some of the key technical points concerning the monti (for instance, the presumed illicit nature of asking for interest on capital lent), but there were some deeper distinctions that divided them. In his defense of free loans, Bariani characterized the relationship between the employees of the monti and the clients who needed a loan as individual and voluntary. Cajetan, on the other hand, thought that clients of the monti should contribute to the expenses connected with making loans and with employing competent professional functionaries rather than volunteers. These were two related aspects of making loans that had no connection with the size or the duration of the loans. According to Muzzarelli, Cardinal Cajetan moved beyond generic models of charity because he was convinced that the monte's purpose of promoting social solidarity had to be governed though rational organization. ${ }^{27}$

The juridical contexts for the monti were as significant as the theological ones, and recent studies on legal consulting have stressed the value of legal opinions (consilia) as a rich and privileged source for the study of social institutions like monti di pieta. ${ }^{28}$ Late medieval and Renaissance jurists like Fortunato Coppoli, Benedetto Capra, and Giovanni Battista Caccialupi produced many consilia in defense of the monti that amplified the preachers' ideas regarding the monti di pietà. ${ }^{29}$ In particular, Annius of Viterbo defined the intended beneficiaries as pauperes pinguiores - that is, those who were not destitute but who periodically (e.g., during feast days) lacked sufficient food and could not provide for their home and family. This was a large segment of the population that the monti di pietà served well. ${ }^{30}$ The pauperes pinguiores were distinct from the miserably poor and destitute, who could turn to other charitable institutions like confraternities, hospitals, convents and monasteries, and other pious initiatives. It was not by chance that the pauperes pinguiores were asked to guarantee their loans with pawns, as a sign that they were not vagabonds. It was clear that the clients of the monte could be indigent but were expected not to be so desperate as to solicit alms. ${ }^{31}$

It is not the private documents of the monte that permit us to discern what types of people were clients, but rather the account books. These can give 
direct knowledge of the economic situation faced by commercial agencies, families, communes, and even pious foundations. ${ }^{32}$ Monte statutes typically stipulated that they must keep several registers: the Pistoia monte, for example, was obliged to keep up more than five of them. These included both elementary or preparatory accounting registers (quaderno di cassa) and also more complex or definitive ones (libro mastro and libro giornale). Studying these registers requires special technical knowledge, and this led some historians in the past to ignore them. ${ }^{33}$

Fortunately this situation has changed and modern historians work extensively with the registers and even publish editions of them. In a recent essay collection on account books, eleven authors systematically investigated accounting techniques used in the major Italian monti, noting that the obligation dictated by their statutes to retain their accounting registers was not always observed, so that many such books have been lost. ${ }^{34}$ The extant registers show great complexity: most monti officials (with the notable exception of the Tuscans) used double-entry bookkeeping. The purpose of accounting within the monti was different from that of mercantile operations: merchants wanted to track variations in assets while monte officials aimed to maintain a balance between income and expenditures in order to assure stability and continuity. ${ }^{35}$ This gave particular responsibility both to the person responsible for keeping money lent to the monte and to the massaro who kept the pawn items and who verified that clients were not destitute but were legitimate pauperes pinguiores. In this context it makes little sense to debate whether the monti were charitable institutions or banks. The monti emerged to charitably provide credit to the pauperes pinguiores but according to rational banking procedures.

\section{Franciscans, Jews, and local dynamics}

The German historian Herbert Holzapfel wrote a pioneering study in 1903 which presented the monti di pietà as particularly Franciscan institutions and a concrete example of the Franciscans' compassion for the weakest classes of society. Many later historians picked up on this theme and presented the monti as central to a Franciscan Observant strategy of limiting recourse to Jewish moneylenders. ${ }^{36}$ Some have emphasized that this element was strongest for the founders of the first monti in north-central Italy, and that Franciscan 
Observant preaching, which frequently included strongly anti-Semitic themes, was indeed vital for the foundation of the monti di pietà. Yet it is equally clear that local monti were shaped by local dynamics, and that these often moderated exclusionary prejudices and changed institutions after a few decades. ${ }^{37}$

Giacomo Todeschini recently argued that Franciscan theologians introduced the principle that interest was licit when it served the public interest (utilitas publica), and that this constituted a concept of both the economic and the moral productivity of wealth that the monti di pietà translated to a practical plane ${ }^{38}$ The monti di pietà were a result of the distinct moral theology of the Franciscan Order, which departed from the traditional positions of medieval Scholasticism on usury. Yet on examining the historical context in which it developed, one finds that Franciscan moral theology seems to have been somewhat less innovative and more consistent with mainstream teachings. ${ }^{39}$ Giovanni Ceccarelli has connected the principal Scholastic statements on the economy to the history of medieval thought, and finds that the monti di pietà are in the most direct practical tradition. A number of other historians have followed the same theme, arguing that in spite of sharp differences on points of detail or of practical application, medieval Scholastics were fundamentally in agreement concerning methods and principles in the treatment of economic themes. ${ }^{40}$

It is commonly believed that the Franciscan Observants preached the institution of the monti di pietà because they were more attentive to the needs of the unfortunate than the Dominicans and the Augustinians, who were more inclined to philosophical speculation. Yet the facts do not always support this. Dominican friars Annius of Viterbo and Girolamo Savonarola were two high profile supporters of monti within the Dominican Order, and the latter was a founder of Florence's monte in 1496. In southern Italy, where monti di pietà were founded from the early sixteenth century, the impetus came largely from merchants, nobles, and members of confraternities.

Regardless of where they were founded or by whom, most monti followed the operational patterns set by private banks, both Christian and Jewish. Jews were particularly active in the small and middling cities of Italy, where no major banks operated, and where from the latter half of the thirteenth century civic authorities signed agreements (condotte) with Jewish moneylenders allowing the latter to offer credit under certain conditions. ${ }^{41}$ Historians have noted that these agreements could move beyond simple loans, and that by controlling the 
credit market, Jewish lenders could influence civic economic policy. ${ }^{42}$ In some of these cities charitable monti co-existed with Jewish lending, which though more expensive served those who were not pauperes pinguiores. While it might seem contradictory that Jewish banks and Christian monti di pietà could coexist and compete with one another, the monti di pietà's promotors, and chiefly Franciscan Observant preachers, argued that charitable pawn banks existed to break the hold of Jewish lenders on the poorest and most indebted segments of the population.

Recent scholarship re-evaluates Christian-Jewish relations in urban areas. ${ }^{43}$ A consilium of the jurist Paolo di Castro (d. 1441), while emphasizing the need to regulate such activities with strict condotte, supported the lending activity of Jewish bankers as necessarius et salutifer in a society that needed monetary liquidity. ${ }^{44}$ A study of the Franciscan Observant Bernardino da Feltre, notorious for powerfully anti-Semitic sermons delivered across north and central Italy, suggests that this anti-Jewish element was not in fact the most dominant element in his preaching. ${ }^{45}$ While many preachers called for Jewish moneylenders to be eliminated, local authorities were often reluctant to lose a source of ready capital.

The commune of Rieti provides an example of the kind of tense co-existence that resulted. Beginning in the late fourteenth century, Rieti welcomed Jewish moneylenders and negotiated a condotta with the unusually long duration of 32 years. Through the fifteenth century, communal regulations grew more stringent as the commune sought to control lending activity. A first attempt to establish a monte di pietà in 1473 failed, but in 1489 the preachers Bernardino da Feltre and Andrea da Faenza founded a monte di pietà and a monte frumentario. While one study of the statutes of the grain monte suggested that the Jewish moneylenders were operating in clear opposition to the civic authorities, Anna Esposito's study of council debates and decisions shows that authorities in Rieti consciously maintained both the older Jewish and newer Christian forms of credit. ${ }^{46}$ Jewish lenders met all requests, including those of the communal authorities, albeit at a higher rate of interest, while the monte assisted only the working poor who periodically ran short of ready funds.

Other recent comparative studies confirm this co-existence of Jewish and Christian banking. Credit relations between Christian and Jewish lenders were complex, and to simplify the relation risks exaggerating some aspects of it. In the Marche, the monti had little initial capital and loaned money without 
interest to a select group of borrowers, with the result that they could never substitute fully for the Jewish moneylenders. ${ }^{47}$ In Liguria, one of the oldest monti di pietà, founded in Genoa in 1483, was not promoted by ecclesiastical authorities to eliminate the Jewish banks, but was a joint initiative of such civic institutions as the Banco di San Giorgio, the Office of the Misericordia, and the Pammatone Hospital to assist the working poor. ${ }^{48}$ Daniele Montanari's recent collection of essays on monti and Jewish lenders in different parts of Italy shows this to be a recurring pattern; the contributors consider the parallel diffusion and comparative operations of monti di pietà and Jewish banks, and highlight the local political factors that led the civic authorities to seek the continuation of both forms of credit. ${ }^{49}$

The situation in Lucca, where Jewish moneylenders had operated from the early fifteenth century, was more complicated. Nicholas $\mathrm{V}$ authorized their activity with the bull Quamvis reprobanda of 1452, whose authority was contested by Bernardino da Feltre among others. ${ }^{50}$ Maria Giuseppina Muzzarelli has noted that while Lucchese citizens petitioned for the bull in order to recognize the presence of Jewish moneylenders, in fact it contributed to their leaving the city in 1493 when they no longer found security there. Quamvis reprobanda reflected the broader debate within Lucca regarding provision of credit, a debate that extended beyond Jewish moneylenders or monti di pietà and resonated in regulations passed by the city's General Council regarding the second monte di pietà $(1493-1503){ }^{51}$

\section{Monti di pietà and the Kingdom of Naples}

Discussion of the monti di pietà in southern Italy was long confined to general works on the Kingdom of Naples. ${ }^{52}$ Giambattista Gifuni's attempt in 1801 to trace the development of the Kingdom's monti from documents inspired no followers. ${ }^{53}$ General works that considered the monti di pietà within the model of the charitable institutions dedicated to aiding the poor noted that as early as the latter half of the sixteenth century, those institutions paid careful attention to the financial and credit markets. The monti were considered variations on the public banks, which spread rapidly in southern Italy in the later Middle Ages, and on the use of certificates known as fedi di credito. ${ }^{54}$ Between the fifteenth and sixteenth centuries, congregations of laymen in southern Italy ran 
hospitals, confraternities, and monti di pietà, and the Viceroys recognized the important work they did in collecting savings and distributing credit by giving them the title of "public banks."

The term "public" was not intended to distinguish between public and private banks, but rather referred to the fede pubblica - that is, to the sort of service they offered. Because it was carried out in favour of city-dwellers, it should be regulated in the public interest. Authorities set up substantial formal requirements that had to be met before a bank could be opened, the first of which was adequate real and personal guarantees. A decisive step in the development of the monti di pietà in the Kingdom of Naples was the concession of a privilege that permitted the state to accept the fedi di credito provided by the monti as a receipt that could be redeemed by third parties for cash. This essentially recognized the paper receipts of the monte as legal currency.

It was once commonly thought that demands for high rates of interest by Jewish moneylenders in southern Italy triggered the founding of local monti di pietà, but this was not in fact the case.${ }^{55}$ Jewish moneylenders multiplied in number in the fifteenth and sixteenth centuries, thanks in large part to their expulsion from the Iberian Peninsula and migration to the Kingdom of Naples after 1492. Yet most of their loans were extended to agrarian producers, and they participated very little in public finance. ${ }^{56}$ Riccardo Filangieri published the first monograph on the monti di pietà in Naples in 1940; Raymond De Roover dismissed it as "an amateurish, but beautifully illustrated volume." De Roover himself focused on the fedi di credito, which he thought were not a prototype of banknotes but rather a form of deposit certificate that only gradually came into general circulation. ${ }^{57}$

Studies written in recent decades have emphasized the monti di pietà as public banks and have further discussed the fedi di credito. ${ }^{58}$ Paola Avallone has been particularly active with a series of detailed studies. She sees the monti in southern Italy reflecting models established in central Italy, and agrees with Muzzarelli that the pauperes pinguiores were the typical users of the southern monti. Avallone notes that free pawning was common with that clientele because most of the monti of southern Italy were founded with capital from confraternities and other charitable institutions, and that only later were these funds expanded with donations and offerings. The greatest difference between the southern monti and those of the rest of the Italian Peninsula was juridical: 
the southern monti gradually freed themselves of all ecclesiastical supervision, requesting recognition - regio assenso - only of the court in Naples. ${ }^{59}$

Avallone and Angela Sinisi have both produced surveys of the monti in southern Italy, relying on detailed maps and graphs to show the areas of the Kingdom of Naples where the better-known monti were located. ${ }^{60}$ The oldest monte di pietà in southern Italy was founded in Lecce in 1520. Puglia was one of the regions with the greatest number of monti, yet like many other southern Italian cities and regions, and unlike Naples itself, it does not have more than a small number of studies dedicated to individual monti. ${ }^{61}$ Bari stands out, in part because the archival records include two rare account books, although the local history unfortunately does little with them. ${ }^{62}$ This is common among most historians of the monti di pietà of southern Italy, who are usually local historians intent on uncovering the origins and local characteristics of their institutions, such as their relationship with confraternities and hospitals. This common connection between monti and charitable institutions was once thought to be a unique characteristic of southern Italy. In fact, recent studies of central and northern Italy have shown similar close connections between the monti and charitable operations in Brescia, Crema, and Cremona. ${ }^{63}$

\section{Studies in English}

Until recently, there have been few studies of monti di pietà in English, and even standard business histories included little or nothing about them. ${ }^{64}$ English language essays on particular monti or themes such as credit facilities for the poor have appeared in recent international collections, and this can help those who are interested in the question both for major centres such as Naples, Florence, Bologna, or Venice, and less-studied places such as Avignon, Malta, Istria and Dalmatia, and even Ottoman Turkey. ${ }^{65}$ These essays explain the popularity of the institution of the monti di pietà even in areas not considered part of the mainstream in studies of the pawn banks.

The first influential study in English appeared in an article by Abbot P. Usher in 1934. Usher considered the monti of Naples to be genuine banks that, as an outgrowth of confraternities and hospitals, maintained names and functions different from those of the original institutions. ${ }^{66}$ His death in 1965 prevented Usher from completing his studies on the banking system of southern Italy and 
developing his reflections on public banking there. Raymond De Roover briefly took up these references, combining them with a reading of Filangieri and with the reconstruction of the Venetian Pisani, Lippomano, Garzone, and Agostini banks (1499-1500) and of the Pisani-Tiepolo bank (1584). Frederic C. Lane dealt with them indirectly in reference to the founding of a public bank on the part of the Venetian government, the Banco della Piazza di Rialto (1587). ${ }^{67} \mathrm{He}$ neglected to define what a "public bank" was, though De Roover expanded on the point and noted that the public banks were founded after "the disappearance of the private banks ... under the auspices of charitable foundations, such as [the] monte di pietà, the foundling hospital, the hospice for incurables, etc." It was those banks that furnished capital to the monti di pietà, which specialized in "pawnbroking, that is in making small loans, secured by pledges, to the needy" ${ }^{68}$ Even in his late works, De Roover insisted on the public nature of the monti di pietà, defining them as "public pawnshops, which charged just enough interest to cover operating costs" and as "credit rather than profitmaking institutions, which advanced small sums to people of modest means." ${ }^{19}$ For De Roover, the foundation of the monti di pietà represented a more constructive approach to the medieval usury prohibition than did the theoretical constructions of the casuists: the monti distributed credit at modest interest rates, making loans possible without contradicting the usury prohibition. ${ }^{70}$

De Roover was less positive about the experience of the monti than other scholars. He probably was thinking of the failure of the monti in Flanders, when Archduke Albert VII of Austria and Archduchess Isabella decided to substitute deposit banks for the private banks. As De Roover states, "the capital of the 'monts-de-piété' was soon depleted by mismanagement, forced government loans, and outright dishonesty." ${ }^{\prime 1}$ Subsequent studies have thrown new light on the Flemish monts-de-piété. Myriam Greilsammer assigns a decisive role to the Jesuits and to the theologian Leonardus Lessius, as Todeschini had done with the Franciscan theologians, while Herman van der Wee demonstrates that the archducal couple, Albert and Isabella, wanted to put into effect a centrist policy that would end the monopoly of the credit market by the private banks, using the Italian monti di pietà as their explicit model. ${ }^{72}$

Brian S. Pullan devoted one-third of his 1970 Rich and Poor in Renaissance Venice to the monti di pietà. Aware of the failures of the private banks of Venice, he concluded that the monti di pietà of the Veneto were equivalent in some ways to the public banks of southern Italy even though they operated 
essentially as charitable institutions. ${ }^{73}$ Venice itself never established a monte di pietà, preferring to force Jewish moneylenders to lend at low rates to the poor, so Pullan focused his research on the diffusion of the monti in the Venetian terraferma. Reinhold C. Muller's lengthy review synthesized Pullan's ideas, noting that while they were supposedly intended to replace Jewish banks they in fact co-existed with them. ${ }^{74}$ Mueller cited the wry comment of a French traveller to Venice of the latter sixteenth century: “Je crois qu'il n'y a qu'à Venise où le Mont-de-Piété s'exerce par les Juifs" ("I think that nowhere but in Venice is the Monte di Pietà run by the Jews"). ${ }^{75}$

According to Paola Lanaro, Pullan provided an able description of the development of the monti from centres of distribution to centres of collection in the Veneto and showed how the sixteenth-century monti di pietà ended up serving functions quite different from those for which they had been conceived. ${ }^{76}$ Pullan later reconsidered some of his findings, but still stressed the public and charitable character of the monti. He also recognized that often bureaucratic procedures for selecting among the pauperes pinguiores worked to the advantage of the Jewish moneylenders, who were less fastidious, and that this in part invalidated the original inspiration of the monti. ${ }^{77}$

The Florentine monte di pietà has been studied, for the most part, by English-speaking scholars. ${ }^{78}$ One of the first studies was by Frank R. Salter, who explained the emergence of the Florentine monte as a reaction, directed by Savonarola, against the Jewish banks and their supporters, the Medici. Some historians have argued instead that Savonarola was guided more by a desire to suppress private banks than by his opposition to Jews or usury. ${ }^{79}$ Carol Bresnahan Menning has published several noteworthy studies on Florence's monte di pietà, dealing with it less in the context of anti-Semitism or religious reform than that of state development. Her first study describes the change in the nature of the institution as it gradually became the bank of Grand Duke Cosimo I de' Medici, who made use of loans granted by the monte to reward his supporters and consolidate his own personal power. ${ }^{80}$ In another study, Bresnahan Menning turns to the early decades of the Florence monte di pietà and shows that it was financed not by the populo minuto, as had previously been thought, but by the large sums deposited by local patricians. ${ }^{81}$ Bresnahan Menning stresses that as early as the first decades of the sixteenth century the monte abandoned its initiatives in support of the poor. ${ }^{82}$ The crucial figure here was the first Duke of Florence, Alessandro de' Medici, who, in order to save the 
monte from bankruptcy, permitted it to double its interest rates on loans from 5 percent to 10 percent in the early 1530s. Poorer clients, who were already burdened with higher taxes, suffered, but the monte was transformed from being an institution that distributed loans to the disadvantaged to one that took in deposits from the advantaged. The very stability of the monte attracted a broader clientele eager to deposit its savings. ${ }^{83}$

While Bresnahan Menning focused on political and financial events connected with the Medici dynasty in the sixteenth century, Richard Goldthwaite has surveyed banking activities of the Florentine monte throughout the Renaissance. Like De Roover, Goldthwaite sees the monte as "a pawn and public deposit bank" and emphasizes that what made the monti distinctive was the closer public and moral control exercised over their activities by the authorities. Its most telling characteristic was its transformation into "a public bank," and even into "a genuine savings-and-loan bank." The monte belonged among secondary-level banking institutions like those of the merchant-bankers, the private bank of the Ricci family, and even the charitable institutions of southern Italy ${ }^{84} \mathrm{He}$ found that as the anti-Semitic preaching of the Franciscan Observants moderated in the sixteenth century, the monti ending up imitating the Jewish banks that they claimed to replace. Their broader banking activities gradually differentiated them from other charitable institutions. Goldthwaite follows Noonan, albeit indirectly, in arguing that by recognizing the monti di pietà, city governments implicitly circumvented the prohibition of usury. ${ }^{85} \mathrm{In}$ fact, the Florentine synod of 1574 tightened anti-usury legislation, setting off polemics over the legality of the operations carried on up to that point by the monte. These polemics continued into the seventeenth century and risked diminishing the monte's ability to attract capital. ${ }^{86}$

The monti di pietà of Umbria have been studied by Ariel Toaff, who connects their foundation to anti-Semitic preaching and propaganda of the Franciscan Observants. ${ }^{87}$ Here again, city governments responded not by banning Jewish moneylending, but by engineering co-existence. Toaff shows that the Jewish moneylenders of the principal cities of Umbria continued to carry on their activities even after the rise of the monti di pietà, and that in fact Jewish moneylenders even contributed to the financing of many monti. Following Noonan, Toaff considers usury "a necessary, and perhaps inevitable evil, in spite of its moral and legal condemnation." 88 This meant that communal and religious authorities could easily concoct various compromises between the 
rigidity of Franciscan preaching and the need for the credit provided by Jewish moneylenders. For Toaff, this made it possible to save appearances and forms and led to a weakening of the centuries-old medieval usury prohibition. ${ }^{89}$

The impact of the usury prohibition has also been studied by Elaine $\mathrm{S}$. Tan who stresses the public and charitable character of the monti di pietà. Tan believes that the origins of the monti should be sought in the growing poverty of the fifteenth century and in the consequences of centuries-long controversies regarding interest-bearing loans. These controversies prompted the scholastics to think twice about the medieval laws prohibiting usury and to conclude that the request for a modest interest rate on the part of the monti was preferable to directly protecting the poor from the usurers' charges..$^{90}$

\section{Conclusion}

Modern studies of the monti di pietà have come a long way. They emerged from studies of usury, banking, charity, and anti-Semitism, and in some cases failed to move far beyond parochial questions about founding date and local peculiarities. Their fifteenth- and sixteenth-century history is now far better known, and monographs, conferences, and essay collections have allowed scholarship to move forward into comparative analysis and synthesis both in Italian and English language scholarship. Modern scholars now explain the monti as being a hybrid of charitable institution and bank from the very beginning, and as fundamentally shaped by local dynamics that often ignored abstract theological statements and anti-Semitic propaganda. The seventeenth century remains less well known, although in the last two decades historians have begun analyzing the changes in economic and financial options, the continuation of charitable impulses, and the shifting relationship between the monti and the administrative policies of the urban elites who governed them. ${ }^{91}$ This collection demonstrates how historians are making more use of ledgers and notarial records in order to understand how lenders and borrowers used the monte: how they circumvented rules, what goods they pawned, and how they related to Jewish moneylenders. Through this kind of interdisciplinary research into archival sources, modern scholarship is offering a more fully rounded picture of the economy of makeshifts through which Renaissance and 
early modern Italians negotiated debt and developed the financial tools for the expansion of a commercial society.

\section{Notes}

1. I am grateful to Lydia G. Cochrane for her translation, to Julius Kirshner of the University of Chicago and Nicholas Terpstra for generous help with the translation and many valuable comments and criticisms, and to the anonymous reader of this article for a number of important bibliographical references.

2. Federigo Melis, "La grande conquista trecentesca del 'credito di esercizio' e la tipologia dei suoi strumenti fino al XVI secolo," in Credito, banche e investimenti: Secoli XIII-XX, ed. Anna Vannini Marx, Atti della quarta settimana di studio dell'Istituto internazionale di storia economica "F. Datini," Prato, 14-21 April 1972 (Florence: Le Monnier, 1985), pp. 15-25.

3. For a list of early Monti foundations before 1515, see Tommaso Fanfani, "Usura e attività di prestito alle origini dell'Italia moderna," in Storia d'Italia. Annali 23. La banca, ed. Alberto Cova, Salvatore La Francesca, Angelo Moioli and Claudio Bermond (Turin: Einaudi, 2008), pp. 150-83, Tabella 1, p. 166.

4. See Daniele Montanari, “'Mons omnibus subvenit': I monti di pietà fra credito e carità," in Per il quinto centenario del monte di pietà di Brescia (1489-1989), ed. Daniele Montanari, 2 vols. (Travagliato: Officina Grafica Artigiana, 1989), vol. 1, pp. 7-36, esp. p. 21. Stanislao Majarelli and Ugolino Nicolini, Il Monte dei poveri di Perugia: Periodo delle origini: 1462-1474 (Perugia: Banca del Monte di Credito, 1962); Alberto Ghinato, "I monti di pietà istituzione francescana," Picenum Seraphicum 9 (1972), pp. 7-62, esp. p. 35. For a bibliographical orientation, see Mauro Carboni, Monti di pietà e monti frumentari, accessed 13 March 2012, http:// www.fondazionedelmonte.it/CENTRO-STUDI-MONTI/Biblioteca/Libri.aspx.

5. Maria Giuseppina Muzzarelli holds that Perugia was the first (see her article in this collection), observing that the Perugian example was a noted and much-imitated model; in 1487 Pope Innocent VIII wrote to authorities in Cesena advising that they pattern their monte on its example. Maria Giuseppina Muzzarelli, Ebrei e Città d'Italia in Età di Transizione: il caso di Cesena dal XIV al XVI secolo (Bologna: Editrice Clueb, 1984), p. 176.

6. Giuseppe Fabiani, Gli ebrei e il monte di pietà in Ascoli (1942; Rome: Tipografia italiana, 1972); Giacinto Pagnani, "Il punto sui monti di pietà e il contributo di 
mons. Giuseppe Fabiani," Atti e memorie della deputazione di storia patria per le Marche 5 (1966-1967), pp. 111-18; Pagnani, "Una questione di priorità: Ascoli o Perugia?” Picenum Seraphicum 9 (1972), pp. 258-87. Ascoli Piceno's primacy is now considered "somewhat uncertain," hence of "little importance": see Maria Giuseppina Muzzarelli, Il denaro e la salvezza: L'invenzione del Monte di Pietà (Bologna: Il Mulino, 2001), p. 114.

7. Giacinto Pagnani, "Il monte di pietà di Fermo e Recanati e la priorità di quello di Ascoli," Atti e memorie della deputazione di storia patria per le Marche 87 (1982), pp. 435-93, esp. pp. 486-93.

8. Vito Piergiovanni, "Statuti e riformagioni," in Civiltà comunale: Libro, scrittura, documento, Atti del convegno, Genoa, 8-11 November 1988 (Genoa: Società Ligure di Storia Patria, 1989), pp. 79-98. In some cases statutes followed only years after foundation, and the founding bull or decree set out the early rules of operation. Rome's monte was founded in 1539 and statutes followed only in 1581: Federico Arcelli, Gli statuti del 1581 del sacro monte di pietà di Roma (Soveria Mannelli: Rubbettino, 1999), p. 27.

9. Bernardino Ghetti, "Gli ebrei e il monte di pietà in Recanati nei secoli XV e XVI. I," Atti e memorie della reale deputazione di storia patria per le Marche (1907), pp. 11-39; B. Ghetti, "Gli ebrei e il monte di pietà in Recanati nei secoli XV e XVI. II," Atti e memorie della reale deputazione di storia patria per le Marche (1914), pp. 377-434, esp. 412-14.

10. Vincenzo Massaccesi, "Il monte di pietà di Ancona dalle origini alla fine del XVII secolo," Annali della Facoltà di lettere e filosofia dell'Università di Macerata 7 (1974), pp. 55-95. Renzo Franciolini, "Il monte di pietà nella Marca centrale: Il caso di Sassoferrato," and Alberto Mazzacchera, "Origine e soppressione del monte di pietà di Cagli," Quaderni di studi storici 1 (1998), pp. 59-98 and 133-42, respectively.

11. Leading examples include the Fondazione del Monte of Bologna and Ravenna and the Centro Studi sui Monti di Pietà e sul Credito Solidaristico. Mario Maragi, I cinquecento anni del Monte di Bologna (Bologna: Banca del Monte di Bologna e Ravenna, 1973); Lina Grandinetti, Il Monte di pietà di Parma: L'istituto attraverso cinque secoli di vita cittadina (Parma: Banca del Monte, 1976); Bruno Barbero, Giulio Fiaschini, Paola Massa, Marco Ricchebono, and Carlo Varaldo, Savona nel Quattrocento e l'istituzione del monte di pietà (Savona: Cassa di Risparmio, 1980); Mario Bocci, “'Il monte pio' volterrano," in Michele Luzzati and Alessandra Veronese, Banche e banchieri a Volterra nel Medioevo e nel Rinascimento (Pisa: 
Pacini, 1993), pp. 165-205; Il Santo Monte di Pietà e la Cassa di risparmio in Reggio Emilia: Cinque secoli di vita di promozione economica e civile, ed. Giuseppe Adani and Paolo Prodi (Reggio Emilia: Cassa di Risparmio di Reggio Emilia, 1994); Giuseppe De Troia and Italia Piacente, Dal Monte di Pietà di Foggia alla Banca del Monte di Foggia: 1587-2000 (Foggia: Banca del Monte, 2001). The scholarship in these volumes is often uneven, with some being richer in colour illustrations than in sustained analysis. Yet many include extensive transcriptions of early documents. For an example of a particularly valuable volume, see Majarelli and Nicolini, Il Monte dei poveri di Perugia, cited in note 4, above.

12. Gino Luzzatto, "Banca," in Enciclopedia Italiana di scienze, lettere ed arti, 36 vols. (Rome: Istituto Giovanni Treccani, 1925-2007), vol. 6 (1930), pp. 35-37; Armando Sapori, "Monti di pietà," in Enciclopedia Italiana, vol. 23 (1934), pp. 725-27.

13. Giovanni Mira, "Alcuni aspetti del credito su pegno in Umbria nei secoli XV e XVI," in Credito, banche e investimenti. Secoli XIII-XX. Prato, 14-21 aprile 1971, ed. Anna Vannini Marx (Fondazione Istituto Internazionale di Storia Economica “F. Datini”: Florence, 1985), p. 119.

14. Sapori also compiled a brief bibliography on the monti di pietà: Armando Sapori, "Saggio di una bibliografia per la storia della banca in Italia fino al 1815," in History of the Principal Public Banks, ed. J. G. Van Dillen (1934; New York: A. M. Kelley, 1964), pp. 357-84.

15. Gino Barbieri, "Origine ed evoluzione storica dei monti i pietà in Italia," Economia e credito 1 (1961), pp. 461-71, esp. p. 465. Gino Barbieri, "Il beato Bernardino da Feltre nella storia sociale del Rinascimento," in Barbieri, Il pensiero economico dall'antichità al Rinascimento (Bari: Istituto di storia economica, Università di Bari, 1963), pp. 376-445, esp. p. 429. Sapori and Barbieri collaborated on the two volumes of the Archivi storici delle aziende di credito. The first volume contains essays wholly dedicated to the monti di pietà of the principal cities of Italy, while Part II offers historical information on the credit agencies such as the Monte dei Paschi of Siena that have historical archives. That second volume constitutes a sort of inventory and guide to the historical archives of the major credit institutions. See Armando Sapori, "Presentazione," and Gino Barbieri, "I lineamenti dell'opera," in Archivi storici delle aziende di credito, vol. 1, pp. vii-xii and xv-xx, respectively.

16. Julius Kirshner, "Les travaux de Raymond de Roover sur la pensée économique des scolastiques," Annales E. S. C. 30.2-3 (1975), pp. 318-38, esp. p. 329. 
17. Giuseppe Garrani, Il carattere bancario e l'evoluzione strutturale dei primigenii monti di pietà: Riflessi della tecnica bancaria antica su quella moderna (Milan: Giuffrè, 1957), p. 31.

18. Ovidio Capitani, review of John T. Noonan, Jr., The Scholastic Analysis of Usury, in Bullettino dell'Istituto storico italiano per il medioevo e archivio muratoriano 70 (1958), pp. 539-66, esp. pp. 548-49, n. 1. This note was omitted when Capitani republished his review as "Sulla questione dell'usura nel Medioevo," in L'etica economica medievale, ed. Ovidio Capitani (Bologna: Il Mulino, 1974), pp. 23-46.

19. Ilvo Capecchi and Lucia Gai, Il Monte della pietà a Pistoia e le sue origini (Florence: Leo S. Olschki, 1976); David Herlihy, Medieval and Renaissance Pistoia: The Social History of an Italian Town (New Haven: Yale University Press, 1967); Ludovico Zdekauer, L'interno di un Banco di pegno nel 1417 con documenti inediti (Florence: M. Cellini \& C., 1896).

20. Capecchi and Gai, Il Monte della pietà, p. 114.

21. Alle origini della Banca: Etica e sviluppo economico, ed. Tommaso Fanfani (Rome: Bancaria, 2002); Tommaso Fanfani, "Usura e attività di prestito alle origini dell'Italia moderna," in Storia d'Italia: Annali XXIII: La banca, ed. Alberto Cova, Sofia La Francesca, Angela Moioli, and Claudio Bermond (Turin: Einaudi, 2008), pp. 150-83. Paolo Prodi, "La nascita dei monti di pietà tra solidarismo cristiano e logica del profitto," in La presenza francescana tra medioevo e modernità, ed. Mario Chessa and Marco Poli (Florence: Vallecchi, 1996), pp. 17-28, esp. p. 20.

22. Christopher F. Black, Italian Confraternities in the Sixteenth Century (Cambridge: Cambridge University Press, 1989), pp. 228-30; V. Gallotta, "Le diocese pugliesi fra '500 e '600,' in V. Garofolo, ed., Cultura e Società nel sec. XVII. Atti del Seminario di Studi. (Bitonto: Centro Ricerche di Storia e Arte, 1980); Angelo D’Ambrosio, "Le confraternite a Trelizzi nel '700: situazione economica e normativa," in Le Confraternite Pugliesi in età moderna, ed. Liana Bertoldi Lenoci (Fasano: Schena Editore, 1988), pp. 375-402, esp. pp. 384-86: “S. Monte della Pietà”; Giuseppe Di Molfetta, "Confraternite e regime pastorale nella città-diocesi di Bisceglie nei secoli XVI-XVIII," in Le Confraternite Pugliesi in età moderna, vol. 2, ed. Liana Bertoldi Lenoci (Fasano: Schena Editore, 1990), pp. 645-74, esp. pp. 651-53: "Il Monte di Pietà e l'ospedale."

23. John Thomas Noonan, Jr., The Scholastic Analysis of Usury (Cambridge, MA: Harvard University Press, 1957), pp. 294-31, esp. pp. 295-99.

24. Maria Giuseppina Muzzarelli, “Un 'deposito apostolico’ per i poveri meno poveri, ovvero l'invenzione del monte di pietà," in Povertà e innovazione istituzionali 
in Italia: Dal medioevo ad oggi, ed. Vera Zamagni (Bologna: Il Mulino, 2000), pp. 77-94, esp. pp. 78-79.

25. Ovidio Capitani, "Nuove acquisizioni del pensiero etico-economico francescano del Basso Medioevo," in La presenza francescana, pp. 39-51, esp. pp. 46-47; Paolo Grossi, "Somme penitenziali, diritto canonico, diritto comune," Annali della Facoltà di Giurisprudenza di Macerata 1 (1966), pp. 95-134, esp. pp. 131-32; Giacomo Todeschini, I mercanti e il tempio: La società cristiana e il circolo virtuoso della ricchezza fra medioevo ed età moderna (Bologna: Il Mulino, 2002), pp. 99-100.

26. Barbieri, "Il beato Bernardino da Feltre," pp. 432-39.

27. Maria Giuseppina Muzzarelli, "Il Gaetano e il Bariani: Per una revisione della tematica sui monti di pietà," Rivista di storia e letteratura religiosa 16 (1980), pp. 3-19.

28. Legal Consulting in the Civil Law Tradition, ed. Mario Ascheri, Ingrid Baumgärtner, and Julius Kirshner (Berkeley: Robbins Collection, 1999).

29. Hélène Angiolini, "I 'consilia' quale fonte per la vita economica: Alcuni problemi," in Legal Consulting in the Civil Law Tradition, pp. 293-315; Mario Ascheri, "G. B. Caccialupi (1420 ca. -1496) fautore dei Monti di pietà," in Grundlagen des Rechts: Festschrift für Peter Landau zum 65. Geburtstag, ed. Richard H. Helmholz, Paul Mikat, Jörg Müller, and Michael Stolleis (Paderborn: Schöningh, 2000), pp. 643-53; Maria Giuseppina Muzzarelli, “'Candelabrum lucem ferens': Il prestito del monte di pietà nel pensiero dei giuristi Benedetto Capra e Baglione dei Montevibiani," in Credito e usura fra teologia, diritto e amministrazione: Linguaggi a confronto (sec. $X V-X V I)$, ed. Diego Guaglioni, Giacomo Todeschini, Gian Maria Varanini, Atti del convegno internazionale, Trento, Istituto trentino di cultura, 3-5 September 2001 (Rome: École française de Rome, 2005), pp. 181-96; Rodolfo Savelli, "Aspetti del dibattito quattrocentesco sui monti di pietà: 'consilia' e 'tractatus," in Banchi pubblici, banchi privati e monti di pietà nell'Europa preindustriale: Amministrazione, tecniche operative e ruoli economici, Atti del convegno, Genoa, 1-6 October 1990, 2 vols. (Genoa: Società ligure di storia patria, 1991), vol. 1, pp. 541-60. Bernardino da Feltre always carried with him a compendium of consilia entitled Pro monte pietatis consilia. Consilia sacrorum Theologorum ac collegiorum Patavii et Perusii. Clarissimorumque doctorum dd. Ioannis Baptiste Rozelli et Ioannis Campegii. Cum bulla ac brevi dato fratri Barnardino Feltrensi Sacratissimi Pape Innocenti Octavi (Venetiis: Joannes Tacuinus de Tridino, 1498); for a transcription and translation see Saverio Amadori, Nelle bisacce di Bernardino da Feltre: Gli scritti giuridici in difesa dei monti di pietà (Bologna: Compositori, 2007). 
30. Annius of Viterbo, "Questiones due disputate super mutuo iudaico et civili et divino," in Amadori, Nelle bisacce di Bernardino da Feltre, pp. 230-73, esp. pp. 250-53. Maria Giuseppina Muzzarelli, "Un bilancio storiografico sui monti di pietà: 1956-1976," Rivista di storia della chiesa in Italia 33 (1979), pp. 165-83, esp. p. 172, n. 42 .

31. Muzzarelli, "Il Gaetano e il Bariani," p. 11.

32. Federigo Melis, Sulle fonti della storia economica: Appunti raccolti alle lezioni del Prof. Federico Melis, ed. Bruno Dini (Milan: Cisalpino-La Goliardica, 1985), p. 117.

33. “Capituli nuovi (1474)," in Capecchi and Gai, Il Monte della pietà a Pistoia, pp. 154-62, esp. pp. 160-61. Mauro Carboni, "Razionalità economica, scritture contabili e Monti di Pietà," in Il Giornale del Monte della Pietà di Bologna: Studi e edizione del più antico registro contabile del Monte di Pietà di Bologna (1473-1519), ed. Armando Antonelli (Argelato: Minerva, 2003), pp. 25-28, esp. p. 26. Among earlier studies that put the accounting sources of the monti di pietà to good use, see Piero Compostella, "Cenni storici sul monte di pietà di Milano," Archivi storici delle aziende di credito, vol. 1, pp. 653-77; Marcello Berti, "Note sull'organizzazione e sull'amministrazione del monte di pietà di Pisa (secoli XVI-XVIII)," in Credito e sviluppo economico in Italia dal Medioevo all'Età Contemporanea, Atti del primo convegno nazionale della Società italiana di storia dell'economia, 4-6 June 1987 (Verona: Selci Umbro, 1988), pp. 307-23.

34. I conti dei Monti: Teoria e pratica amministrativa nei Monti di Pietà fra Medioevo ed Età Moderna, ed. Mauro Carboni and Maria Giuseppina Muzzarelli (Venice: Marsilio, 2008). See also the review of this work by Nicola Lorenzo Barile in Nuova rivista storica 94 (2010), pp. 1016-19.

35. Paola Pinelli, “'Ragguagliare ai tempi debiti le partite dell'entrate et uscite': La contabilità dei Monti Pii toscani tra XV e XVI secolo," in I conti dei Monti, pp. 113-30, esp. p. 114.

36. Heribert Holzapfel, Die Anfänge der Montes Pietatis (1462-1515) (Munich: J. J. Lentner, 1903). Mariano D’Alatri, "Francescani e banchieri ebrei nelle città d'Italia durante il Quattrocento," Picenum seraphicum 9 (1972), pp. 63-73; Alberto Ghinato, Studi e documenti intorno ai primitivi monti di pietà, 5 vols. (Rome: Edizioni Francescane, 1963); Vittorino Meneghin, I monti di pietà in Italia dal 1462 al 1562 (Vicenza: L.I.E.F., 1986); Vittorio Meneghin, Bernardino da Feltre e $i$ monti di pietà (Vicenza: L.I.E.F., 1974). 
37. Renata Segre, "Bernardino da Feltre i monti di pietà e i banchi ebraici," Rivista storica italiana 9 (1978), pp. 818-33, esp. p. 825; Rodolfo Savelli, "Aspetti del dibattito quattrocentesco"; Savelli, "Diritto romano e teologia riformata: Du Moulin di fronte al problema dell'interesse del denaro," Materiali per una storia della cultura giuridica 23 (1993), pp. 291-324; Maria Giuseppina Muzzarelli, “I Francescani ed il problema dei Monti di pietà," in Atti del convegno storico bernardiniano in occasione del sesto centenario della nascita di S. Bernardino da Siena, L'Aquila, 7-9 maggio 1980 (L'Aquila: Comitato Aquilano del Sesto Centenario di S. Bernardino da Siena, 1982), pp. 83-95; Franco Mormando, The Preacher's Demons: Bernardino of Siena and the Social Underworld of Renaissance Italy (Chicago: University of Chicago Press, 1999).

38. Giacomo Todeschini, Franciscan Wealth: From Voluntary Poverty to Market Society (Saint Bonaventura NY: Franciscan Institute, Saint Bonaventura University, 2009).

39. Julius Kirshner and Kimberly Lo Prete, "Peter John Olivi's treatises on contracts of sale, usury and restitution: Minorite economics or minor works?” Quaderni fiorentini 13 (1984), pp. 233-86. See also in this context: H. Baron, "Franciscan Poverty and Civic Wealth as Factors in the Rise of Humanistic Thought," Speculum 13 (1938), pp. 1-37.

40. Giovanni Ceccarelli, "Etica economica e monti di pietà," in L'Italia alla fine del medioevo: I caratteri originali nel quadro europeo, ed. Federica Cengarle, 2 vols. (Florence: Firenze University Press, 2006), vol. 2, pp. 127-66, esp. p. 134. Raymond De Roover, "Scholastic Economics: Survival and Lasting Influence from the Sixteenth Century to Adam Smith," Quarterly Journal of Economics 69 (1955), pp. 161-90, esp. p. 180; now available in De Roover, Business, Banking and Economic Thought in Late Medieval and Early Modern Europe, ed. Julius Kirshner (Chicago and London: The University of Chicago Press, 1974), pp. 306-35, esp. p. 325. Moreover, Ceccarelli contradicts himself when, soon after having asserted the universalism of medieval Scholasticism, he admits that the proposal to establish the monti occurred in Italy and not elsewhere: Ceccarelli, p. 164.

41. Michele Luzzati, "Banchi e insediamenti ebraici nell'Italia centro-settentrionale fra tardo Medioevo e inizi dell'Età moderna," in Gli Ebrei in Italia: Storia d'Italia: Annali XI: Gli Ebrei, ed. C. Vivanti, part 1, Dal Medioevo all'età dei ghetti (Turin: Einaudi, 1996), pp. 173-235.

42. Giuseppe Laras, "Evoluzione del concetto di usura del giudaismo e riflessioni sui moventi della critica minoritica nei confronti del prestito ebraico," Picenum seraphicum 9 (1972), pp. 74-88; Attilio Milano, “Considerazioni sulla lotta dei monti 
di pietà contro il prestito ebraico," in Scritti in memoria di Sally Mayer (Jerusalem: Fondazione Sally Mayer, 1956), pp. 199-223.

43. Maria Giuseppina Muzzarelli, "Luoghi e tendenze dell'attuale storiografia italiana sulla presenza ebraica fra XIV e XVI secolo," Società e storia 24 (1984), pp. 369-94, esp. p. 374.

44. Paulus de Castro, Consiliorum sive responsorum volumen, 3 vols. (Venetiis: apud Ioannem Baptistam Somascum et fratres, 1570), vol. 1, fols. 77r-v (cons. 174) and $144 \mathrm{v}-145 \mathrm{r}$ (cons. 295).

45. Muzzarelli, “Luoghi e tendenze," p. 384.

46. M. Sensi, "Andrea da Faenza istitutore dei monti frumentari," in Picenum Seraphicum 9 (1972), pp. 162-256, esp. 175-78. A. Esposito, "Prestito ebraico e monti di pietà nei territori pontifici nel tardo Quattrocento: il caso di Rieti," in Credito e sviluppo economico, pp. 97-109.

47. La presenza ebraica nelle Marche: Secoli XIII-XX, ed. Sergio Anselmi and Viviana Bonazzoli (Ancona: Proposte e ricerche, 1993).

48. Paola Massa, "Assistenza e credito alle origini dell'esperienza ligure dei monti di pietà," in Banchi pubblici, banchi privati, vol. 2, pp. 593-616; Massa, "Banchi ebraici e monti di pietà in Liguria. Bilancio storiografico e prospettive di ricerca," in Monti di Pietà e presenza ebraica in Italia (secoli XV-XVIII), ed. Daniele Montanari (Rome: Bulzoni, 1999). pp. 17-33.

49. Montanari, ed., see above.

50. For the text of this bull, see Giuseppe Coniglio, "L'usura a Lucca ed una bolla di Niccolò V del 1452," Rivista di storia della chiesa 6 (1952), pp. 259-64, esp. pp. 261-62; Meneghin, Bernardino da Feltre, pp. 215-41.

51. Maria Giuseppina Muzzarelli, "Angelo da Chivasso e i monti di pietà," Bollettino della società per gli studi storici, archeologici ed artistici della provincia di Cuneo 118 (1998), pp. 169-84, esp. pp. 180-84; Domenico Corsi, "Il secondo monte di pietà di Lucca (1493-1502)," Archivio storico italiano 126 (1968), pp. 389-408.

52. Ludovico Bianchini, Storia delle finanze del Regno delle due Sicilie (1860), ed. Luigi De Rosa (Naples: Edizioni Scientifiche Italiane, 1971); Nicola Ferorelli, Gli ebrei nell'Italia meridionale dall'età romana al scolo XVIII (1915), ed. Filena Patroni Griffi (Naples: Dick Peerson, 1990); Pietro Giannone, Istoria civile del regno di Napoli, 3 vols. (Prato: Tipografia Giachetti, 1864/1865); Giovanni Antonio Summonte, Dell'historia della città e del Regno di Napoli, 4 vols. (Naples: A spese di Antonio Bulifon libraro all'insegna della Sirena, 1675). 
53. Giambattista Gifuni, Compendio istorico della origine e fondazione del monte della pietà di Napoli estratta da vari autentici documenti (1801), ed. D. Demarco (Naples: Arte tipografica, 1997).

54. Bianchini, Storia delle finanze, pp. 325-36 and 433-35. G. Muto, "Tra "hombres de negozio' e banchi pubblici: progetti di autonomia finanziaria nello stato napoletano (secoli XVI-XVII)," Studi storici Luigi Simeone 33 (1983), pp. 85-101.

55. Summonte, vol. 4, p. 85.

56. Viviana Bonazzoli, “Gli Ebrei del regno di Napoli all'epoca della loro espulsione. Il periodo spagnolo (1501-1541)," Archivio storico italiano 139 (1981), pp. 179-287, esp. pp. 249 and 256.

57. Riccardo Filangieri, I banchi di Napoli dalle origini alla costituzione del Banco delle Due Sicilie (1539-1808) (Naples: Tip. degli Artigianelli, 1940), pp. 31-64. Raymond De Roover, "New Interpretation of the History of Banking," in De Roover, Business, Banking and Economic Thought, pp. 200-389, esp. pp. 224-25, and n. 107.

58. De Rosa, "Banchi pubblici, banchi privati e monti di pietà a Napoli nei secoli XVI-XVIII," in Banchi pubblici, banchi privati, vol. 1, pp. 497-512; De Rosa, "Gli inizi della circolazione della cartamoneta e i banchi pubblici napoletani," in Gli inizi della circolazione della cartamoneta e i banchi pubblici napoletani, ed. Luigi De Rosa (Naples: Istituto Banco di Napoli-Fondazione, 2002), pp. 437-59; De Rosa, "Larchivio del banco di Napoli e l'attività dei banchi pubblici napoletani," De computis: Revista española de historia de la contabilidad 1 (2004), pp. 54-66.

59. Paola Avallone, "L’organizzazione contabile dei banchi pubblici napoletani tra XVI e XVIII secolo," in L'impresa Industria Commercio Banca Secc. XIII-XVIII, ed. Simonetta Cavaciocchi, Atti della XXII Settimana di studi dell'Istituto internazionale di storia economica "F. Datini," Prato, 30 April-4 May 1990 (Florence: Le Monnier, 1991), pp. 370-83; Paola Avallone, "Dall'assistenza al credito: La diffusione dei Monti di pietà nel regno di Napoli (secc. XV-XVIII)," in Povertà e innovazioni istituzionali, pp. 355-74; Avallone, "Una banca al servizio del 'povero bisognoso': I Monti di Pietà nel Regno di Napoli (secc. XV-XVIII)," in Il "povero" va in banca: I Monti di Pietà negli antichi stati italiani (secc. XV-XVIII), ed. Paola Avallone (Naples: Edizioni Scientifiche Italiane, 2001), pp. 77-130; Avallone, "Organizzazione e contabilità dei Monti di pietà napoletani in epoca moderni," in I conti dei Monti, pp. 233-61; Avallone, "Il credito su pegno nel Regno di Napoli (XVI-XIX secolo)," in Prestare ai poveri: Il credito su pegno e i monti di pietà in area mediterranea, secoli XV-XIX, ed. Paola Avallone (Rome and Naples: Consiglio 
nazionale delle Ricerche, Istituto di Studi sulle Società del Mediterraneo, 2007), pp. 69-100, esp. pp. 77-79 and 85.

60. Paola Avallone, "Dall'assistenza al credito," appendix; Avallone, "Una banca al servizio del 'povero bisognoso," pp. 121-30; Angela Sinisi, "Per una storia dei Monti di Pietà nel Regno di Napoli (secoli XVI-XVIII)," in Monti di Pietà e presenza ebraica, pp. 245-83, esp. pp. 251, 259, and 280-83.

61. Vincenzo Amenduni, Il Monte frumentario in Ruvo (Ruvo, Associazione Turistica Pro Loco, 1959); Pietro Mossa, "Le istituzioni di pubblica beneficenza nella provincia di Bari: Studio storico-statistico-sociale," in La Terra di Bari sotto l'aspetto storico, economico e naturale. Pubblicazione della provincia di Bari per la esposizione universale di Parigi, 2 vols. (1900; Bari: Levante, 1986), vol. 2, pp. A4-A137; Francesco A. Bernardi, "Dai Monti di Pietà alla soppressione degli Enti Comunali di Assistenza: La beneficenza pubblica e privata a Ruvo (XVI-XX sec.)," Odegitria 13 (2006), pp. 245-320; Lorenzo Palumbo, "Enti ecclesiastici e attività creditizia in terra di Bari nel secolo XVIII," in Studi di storia pugliese in onore di Giuseppe Chiarelli, ed. Michele Paone, 4 vols. (Galatina: Congedo, 1972-1980), vol. 4 (1976), pp. 209-28; Le confraternite del Santissimo Sacramento e del Monte di Pietà a Molfetta, ed. Luigi Michele De Palma (Molfetta: Mezzina, 2004). Among the lengthier studies, see Giuseppe De Gennaro, Studi di storia creditizia pugliese dal medioevo all'età moderna (Milan: Giuffrè, 1972); Giovanni Masi, "I Monti frumentari e pecuniari in provincia di Bari," in Studi in onore di Amintore Fanfani, 6 vols. (Milan: Giuffrè, 1962), vol. 5, pp. 340-409.

62. Donato De Capua, "Capitoli, regole e istruzioni del monte i pietà della città di Bitonto (1559)," in Atti del primo congresso europeo di storia ospitaliera, 6-12 June 1960 (Reggio Emilia: Centro Italiano di Storia Ospitaliera, 1962), pp. 402-16; Giovanni Guerrieri, "La fondazione e le vicende del Monte pio di Lecce (1520)," Rassegna pugliese 17 (1900), pp. 142-52, esp. pp. 148-52; Francesco Di Palo “La vera mira al sollievo de poveri': Confraternite tutele sociali e Monti frumentari a Minervino e Montemilone fra '500 e '700,' in Campi solcati: Studi in memoria di Lorenzo Palumbo, ed. Mario Spediato (Galatina: Panico, 2009), pp. 197-220. Vito Antonio Melchiorre, Il Sacro Monte di Pietà e Ospedale Civile di Bari (Bari: Levante, 1992).

63. Paola Avallone and Renata Salvemini, "Dall'assistenza al credito: L'esperienza dei monti di pietà e delle case sante nel Regno di Napoli tra XVI e XVIII secolo," Nuova rivista storica 83 (1999), pp. 21-54. Daniele Montanari, "I monti di pietà della Lombardia (secoli XV-XVIII): prime riflessioni," Annali di storia moderna e 
contemporanea 2 (1996), pp. 9-43; Adelaide Ricci, "Cremona, il suo primo Monte e il 'Consortio de la sancta Pietà,'” in I Monti di pietà fra teoria e prassi. Quattro casi esemplari: Urbino, Cremona, Rovigo, Messina, (Bologna: CLUEB, 2009), pp. 67-99.

64. Norman Scott Brien Gras, Business and Capitalism: An Introduction to Business History (1939) (Washington D.C.: Beard Books, 2003), p. 78; Florence Edler, Glossary of Mediaeval Terms of Business: Italian Series 1200-1600 (1934) (New York: Kraus Reprints, 1970); Roberto S. Lopez and Irving W. Raymond, eds. Medieval Trade in the Mediterranean World: Illustrative Documents Translated with Introductions and Notes (New York: Columbia University Press, 1955). Among the dictionaries and encyclopedias, the authoritative Dictionary of the Middle Ages, edited by Joseph R. Strayer, has no entry on the monti di pietà and makes no specific reference to them, and only recently has the Oxford Encyclopedia of Economic History included an entry on the monti. Dictionary of the Middle Ages, ed. Joseph R. Strayer, 13 vols. (New York: Scribner, 1982-1989); Maria Giuseppina Muzzarelli, "Monte di pietà," in The Oxford Encyclopedia of Economic History, ed. Joel Mokyr, 5 vols. (New York: Oxford University Press, 2003), vol. 4, pp. 1-2.

65. Madeleine Ferrière, “The 'Monte de Piété' of Avignon: From Charitable Credit to Popular Credit (1610-1790)"; Charles Dalli, "Beyond Charity: The Evolution of Credit as Charity in Malta, 1400-1800"; Darko Darovec, "The Monte di Pietà in Istria and Dalmatia"; Eugenia Kermeli, "Debt and Credit in the Ottoman Empire: The Case of Ottoman Crete" - all in Prestare ai poveri, respectively, pp. 157-68; 201-24; 225-44; and 259-71.

66. Abbot P. Usher, "The Origins of Banking: The Primitive Bank of Deposit, 1200-1600,” The Economic History Review 4 (1934), pp. 399-428, esp. p. 427.

67. Frederic C. Lane, "Venetian Bankers, 1495-1533: A Study in the Early Stages of Deposit Banking," Journal of Political Economy 45 (1937), pp. 187-206, now available as "Venetian Bankers, 1495-1593" in Lane, Venice and History: The Collected Papers of Frederic C. Lane (Baltimore: The Johns Hopkins University Press, 1966), pp. 69-86; Lane, Venice: A Maritime Republic (Baltimore: The Johns Hopkins University Press, 1973), pp. 327-31. Lane has written only once about the monti di pietà, defining them simply as "institutions [that] were formed to make loans to the poor": Lane, Venice: A Maritime Republic, p. 304.

68. Raymond De Roover, "Le rôle des italiens dans la formation de la banque moderne," Revue de la banque 9-10 (1952), pp. 640-63, esp. pp. 657-59; De Roover, “New Interpretation," pp. 223-25. In an old article, De Roover had already defined 
the monti di pietà as "public loan offices": De Roover, "The Three Golden Balls of the Pawnbrokers," Bulletin of the Business Historical Society 20 (1946), pp. 117-24.

69. Raymond De Roover, San Bernardino of Siena and Sant'Antonino of Florence: The Two Great Economic Thinkers of the Middle Ages (Boston: Baker Library, Harvard Graduate School of Business Administration, 1967), p. 33; Raymond De Roover, La pensée économique des Scolastiques: Doctrines et méthodes (Montréal and Paris: Institut d'études médiévales, Librairie J. Vrin, 1971), p. 85

70. Raymond De Roover, “The Scholastics, Usury, and Foreign Exchange," Business History Review 41 (1967), pp. 257-70, esp. p. 264.

71. Raymond De Roover, Money, Banking and Credit in Mediaeval Bruges: Italian Merchant-Bankers, Lombards and Money-Changers: A Study in the Origins of Banking (Cambridge, MA: Medieval Academy of America, 1948), p. 130.

72. Myriam Greilsammer, "Il credito al consumo in Europa: Dai 'lombardi' ai Monti di pietà," in Commercio e cultura mercantile, ed. Franco Franceschi, Richard A. Goldthwaite, and Rheinhold C. Mueller, vol. 4 of Il Rinascimento Italiano e l'Europa (Treviso: Fondazione Cassamarca; Costabissara: A. Colla, 2007), pp. 591-621. Herman van deer Wee, The Growth of the Antwerp Market, 3 vols. (The Hague: Martinus Nijhoff, 1963), vol. 2, p. 336.

73. Brian S. Pullan, Rich and Poor in Renaissance Venice: The Social Institutions of a Catholic State, to 1620 (Oxford: Blackwell, and Cambridge MA: Harvard University Press, 1971), pp. 474 and 599-601. Pullan's reconstruction is repeated in Paolo Prodi, "The Structure and Organization of the Church in Renaissance Venice: Suggestion for Research," in Renaissance Venice, ed. J. R. Hale (London: Faber, 1973), pp. 409-30, esp. p. 422.

74. Reinhold C. Mueller, "Charitable Institutions, the Jewish Community and Venetian Society: A Discussion of a Recent Volume by Brian Pullan," Studi Veneziani 14 (1972), pp. 37-82, esp. pp. 64-76.

75. Mueller, "Charitable Institutions," p. 76. For his discussion of the monti as charitable pawn banks, see Mueller, The Venetian Money Market: Banks, Panics, and the Public Debt, 1200-1500 (Baltimore: The Johns Hopkins University Press, 1997), p. 573.

76. Paola Lanaro, "Prestito e carità nei Monti di Pietà: Una riflessione storiografica," in L'uso del denaro: Patrimoni e amministrazione nei luoghi pii e negli enti ecclesiastici in Italia (secoli XV-XVIII), ed. Alessandro Pastore and Marina Garbellotti (Bologna: Il Mulino, 2001), pp. 89-105, esp. p. 95. 
77. Brian S. Pullan, "New Approaches to Poverty and New Forms of Institutional Charity in Late Medieval and Renaissance Italy," in Povertà e innovazioni istituzionali in Italia, pp. 17-43, esp. pp. 38-41.

78. For studies in Italian about the Florentine monte, see Marino Ciardini, I banchieri ebrei in Firenze nel secolo XV e il monte di pietà fondato da Girolamo Savonarola: Appunti di storia economica con appendice di documenti (1907; Firenze: Gozzini, 1975); Geno Pampaloni, “Cenni storici sul Monte di pietà di Firenze," in Archivi storici delle aziende di credito, vol. 1, pp. 525-60; Aldo De Maddalena, "Per la storia dei Monti di pietà: Una memoria cinquecentesca mantovana sull'ordinamento e sul funzionamento del Monte di pietà di Firenze," in Scritti in onore di Giordano Dell'Amore: Saggi monetari e creditizi, 2 vols. (Milan: Giuffrè, 1969), vol. 2, pp. 870-92; Riccardo Fubini, "Prestito ebraico e monte di pietà a Firenze (1471-1473)," in La cultura ebraica all'epoca di Lorenzo il Magnifico: Celebrazioni del V Centenario della morte di Lorenzo il Magnifico, ed. Dora Liscia Bemporad and Ida Zatelli, Convegno di studio, Firenze, Accademia toscana di scienze e lettere “La Colombaria," 29 November 1992 (Florence: Leo S. Olschki, 1998), pp. 101-55. For a study of the Florentine Jewish community which contains some material related to the monte, see Stefanie B. Siegmund, The Medici State and the Ghetto of Florence: The Construction of an Early Modern Jewish Community, Stanford Studies in Jewish History and Culture (Stanford: Stanford University Press, 2006).

79. Frank R. Salter, “The Jews in Fifteenth-Century Florence and Savonarola's Establishment of a 'mons pietatis,'” Cambridge Historical Journal 5 (1935-1937), pp. 193-211; Michele Luzzati and Cristina Galasso, "Primi appunti su Girolamo Savonarola e gli ebrei dello stato fiorentino," in Studi savonaroliani: Verso il V centenario, ed. Gian Carlo Garfagnini, Atti del primo seminario di studi, Florence, 14-15 January 1995 (Florence: SISMEL-Edizioni del Galluzzo 1996), pp. 34-40.

80. Carol Bresnahan Menning, "Loans and Favors, Kin and Clients: Cosimo de' Medici and the Monte di Pietà," Journal of Modern History 61 (1989), pp. 486-511.

81. Carol Bresnahan Menning, “The Monte's 'Monte': The Early Supporters of Florence's Monte di Pietà," The Sixteenth Century Journal 23 (1992), pp. 661-76.

82. Carol Bresnahan Menning, Charity and State in Late Renaissance Italy: The Monte di Pietà of Florence (Ithaca: Cornell University Press, 1993), pp. 86-87.

83. Lanaro, pp. 102-03.

84. Richard C. Goldthwaite, The Economy of Renaissance Florence (Baltimore: The Johns Hopkins University Press, 2009), pp. 468-83. 
85. Richard A. Goldthwaite, "Banking in Florence at the End of the Sixteenth Century," Journal of European Economic History 27 (1998), pp. 471-536, esp. pp. 474, 509-10, $512,515$.

86. Bresnahan Menning, Charity and State, pp. 265-66; Pampaloni, pp. 545-46.

87. Ariel Toaff, "Offensive of the Preaching Fathers and the Foundation of the Monte di Pietà," in Toaff, The Jews in Medieval Assisi, 1305-1487: A Social and Economic History of a Small Jewish Community in Italy (Florence: Leo S. Olschki, 1979), pp. 57-64.

88. Noonan, p. 399.

89. Ariel Toaff, "Jews, Franciscans and the First 'Monti di Pietà' in Italy," in Friars and Jews in the Middle Ages and Renaissance, ed. Steven J. McMichael and Susan E. Myers (Leiden and Boston: Brill, 2004), pp. 239-53, esp. pp. 250-51.

90. Elaine S. Tan, "An Empty Shell? Rethinking the Usury Laws in Medieval Europe," Journal of Legal History 23 (2002), pp. 177-96, esp. pp. 191-92.

91. For example, Massimo Fornasari's study of the monte di pietà of Bologna shows how within a few decades it became something like a common fund in a complex urban system of assistance to the poor and a genuine thesoro della città: Massimo Fornasari, Il "Thesoro" della città: Il monte di pietà e l'economia bolognese nei secoli XV e XVI (Bologna: Il Mulino, 1993). 